\title{
Healthcare Reform out of Nowhere? Policy Reform and the Lack of Programmatic Commitment in Peru
}

\author{
Zoila Ponce de Leon* \\ Assistant Professor of Politics, Washington and Lee University \\ ${ }^{\star}$ Corresponding author. Email: zponcedeleon@wlu.edu
}

(Received 15 April 2020; revised 15 March 2021; accepted 27 April 2021)

\begin{abstract}
The reform approved in Peru in 2009 during a right-wing government deviates from similar attempts in the region to expand access to healthcare. Left-wing parties in Peru were extremely weak during the policy-making process and the political parties were nonprogrammatic. Based on original field research, this article demonstrates how parties that lacked core values uniting their leaders and had no commitment to the health reform did not care for the definition of specifications regarding funding and implementation. Instead, technocrats dominated the process of policy formation, which, accompanied by the lack of commitment from key political actors, led to poorly specified policy and deficient implementation.
\end{abstract}

Keywords: healthcare reform; non-programmatic political parties; technocrats; Peru; Latin American politics; AUS

\section{Introduction}

With the implementation of neoliberal policies in Latin American countries in the 1980s and early 1990s, the region shared a common challenge: an increasing social disparity in access to healthcare. ${ }^{1}$ Latin American countries have attempted to expand access to healthcare and reform a system that discriminates against their citizens based on their socio-economic status. ${ }^{2}$ Just how important it is to understand what leads to unsuccessful healthcare reform has become apparent during the Covid-19 pandemic. In moments of crisis, unsuccessful reforms cost people's lives.

\footnotetext{
${ }^{1}$ Christina Ewig, Second-Wave Neoliberalism: Gender, Race, and Health Sector Reform in Peru (University Park, PA: Pennsylvania State University Press, 2010).

${ }^{2}$ Candelaria Garay, Social Policy Expansion in Latin America (New York: Cambridge University Press, 2016); James W. McGuire, Wealth, Health, and Democracy in East Asia and Latin America (New York: Cambridge University Press, 2010); Jennifer Pribble, Welfare and Party Politics in Latin America (New York: Cambridge University Press, 2013).

(c) The Author(s), 2021. Published by Cambridge University Press
} 
Peru was one of the few countries in the region where the government had an early response to the pandemic. ${ }^{3}$ Despite early efforts to avoid the spread of the virus, the Peruvian government was unable to control it and has struggled to respond to the healthcare needs of its population. The fast increase in cases has led to the collapse of an already strained public healthcare system. With over 5,600 deaths per million people, Peru became the country with the highest mortality rate due to Covid-19 in the world as of June $2021 .{ }^{4}$ The Peruvian reform failed to provide widespread effective access to healthcare.

An important body of literature has focused on the role of left-wing political parties in the development of healthcare reforms, ${ }^{5}$ neglecting a focus on countries where right-wing parties have presided over reforms seeking to expand access to healthcare, as was the case in Peru. ${ }^{6}$ The context of the reform approved in Peru in 2009 during Alan García's Alianza Popular Revolucionaria Americana (American Popular Revolutionary Alliance, APRA) second term - Aseguramiento Universal en Salud (Universal Health Insurance, AUS) - deviates from similar attempts to expand access to healthcare. Left-wing parties in Peru were extremely weak during the AUS policy-making process. This unexpected reform can help us understand the emergence of social policy reform under the weakness of the Left, as well as the quality of such reform. This article analyses how and why right-wing parties promote the expansion of healthcare access.

In contrast to other reforms in countries such as Chile, Mexico or Uruguay, the Peruvian reform was developed under a party system that lacked institutionalisation and with parties that were far from programmatic. ${ }^{7}$ Programmatic parties have core

\footnotetext{
${ }^{3}$ Dan Collins, 'Peru's Coronavirus Response was "Right on Time" - So Why Isn't It Working?', The Guardian, 20 May 2020, available at www.theguardian.com/global-development/2020/may/20/perucoronavirus-lockdown-new-cases, last access 21 May 2021.

${ }^{4}$ Covid-19 statistics are available at www.worldometers.info/coronavirus/, last access 4 June 2021.

${ }^{5}$ Evelyne Huber and John Stephens, 'Successful Social Policy Regimes? Political Economy, Politics, and the Structure of Social Policy in Argentina, Chile, Uruguay, and Costa Rica', in Scott Mainwaring and Timothy R. Scully (eds.), Democratic Governance in Latin America (Stanford, CA: Stanford University Press, 2009), pp. 155-209; Jennifer Pribble and Evelyne Huber, 'Social Policy and Redistribution: Chile and Uruguay', in Steven Levitsky and Kenneth M. Roberts (eds.), The Resurgence of the Latin American Left (Baltimore, MD: Johns Hopkins University Press, 2011), pp. 117-38.

${ }^{6}$ Important exceptions, which analyse efforts to expand social benefits led by right-wing parties, are Christina Ewig, 'Reform and Electoral Competition: Convergence Toward Equity in Latin American Health Sectors', Comparative Political Studies, 49: 2 (2016), pp. 184-218; Garay, Social Policy Expansion; Tasha Fairfield and Candelaria Garay, 'Redistribution under the Right in Latin America: Electoral Competition and Organized Actors in Policymaking', Comparative Political Studies, 50: 14 (2017), pp. 1871-906. See also David Altman and Rossana Castiglioni, 'Determinants of Equitable Social Policy in Latin America (1990-2013)', Journal of Social Policy, 49: 4 (2020), pp. 763-84; Sara Niedzwiecki and Jennifer Pribble, 'Social Policies and Center-Right Governments in Argentina and Chile', Latin American Politics and Society, 59: 3 (2017), pp. 72-97.

${ }^{7}$ Maxwell A. Cameron, 'The Left Turn that Wasn't', in Levitsky and Roberts (eds.), The Resurgence of the Latin American Left, pp. 375-98; Herbert Kitschelt, Kirk A. Hawkins, Juan Pablo Luna, Guillermo Rosas and Elizabeth J. Zechmeister, Latin American Party Systems (New York: Cambridge University Press, 2010); Steven Levitsky, 'Peru: The Institutionalization of Politics without Parties', in Scott Mainwaring (ed.), Party Systems in Latin America: Institutionalization, Decay, and Collapse (New York: Cambridge University Press, 2018), pp. 326-56; Steven Levitsky and Maxwell A. Cameron, 'Democracy without Parties? Political Parties and Regime Change in Fujimori's Peru', Latin American Politics and Society, 45 : 3 (2003), pp. 1-33; Martín Tanaka, 'Perú, 1980-2000: Chronicle of a Death Foretold? Determinism, Political Decisions, and Open
} 
values that unite their leaders and drive the party programme. ${ }^{8}$ Whereas certain policy issues are directly related to the core values of a party, others are not. When parties lack core values, there is no connection between the parties and the policy issue, which determines parties' lack of programmatic commitment to a policy. I argue that this absence of programmatic commitment impacts policymaking, including the quality of the legislation and its implementation. ${ }^{9}$

Two crucial indicators of a reform's success are sustainable funding and infrastructure development. They need to be part of healthcare reform legislation and political parties play crucial roles as policy-makers determining the quality of legislation and implementation. Using over 60 in-depth interviews gathered through original field research, I show how, when parties lack core values, there is no commitment to the policy, or to the definition of its specifications or its implementation. Although legislation still passed, parties were disengaged from the definition of the reform's specifications, which allowed technocrats without partisan ties to dominate the policy-making process in Peru. Technocrats lacking incentives to provide clear policy specifications regarding funding and infrastructure crafted a reform poorly designed for effective implementation.

The findings of this article contribute to the literature on social policy reforms by pointing out how parties' lack of programmatic commitment can have an effect on the policy-making process and final policy. Other studies have shown how nonprogrammatic parties negatively impact democracy and representation. ${ }^{10}$ I show how non-programmatic parties affect policy-making. We know little about social policy reforms in countries like Peru, the so-called 'democracies without parties', where parties are non-programmatic, weak and volatile. ${ }^{11}$ The Peruvian case helps us understand how weak parties, without core values, lead to low-quality policy that lacks political commitment to sustain it. Party systems in the region and across the world are experiencing increasing fragility. We must shed light on how policies are made in this context and what the consequences are.

The study of healthcare reforms in the context of non-programmatic parties can allow us to better understand the role of technocrats. Technocrats' degree of autonomy in the health sector in Peru has changed over time. ${ }^{12}$ While technocrats

Outcomes', in Frances Hagopian and Scott P. Mainwaring (eds.), The Third Wave of Democratization in Latin America: Advances and Setbacks (New York: Cambridge University Press, 2003), pp. 261-88.

${ }^{8}$ Herbert Kitschelt, 'Linkages between Citizens and Politicians in Democratic Polities', Comparative Political Studies, 33: 6/7 (2000), pp. 845-79; Kitschelt et al., Latin American Party Systems; Kenneth M. Roberts, 'Party-Society Linkages and the Transformation of Representation in Latin America', Canadian Journal of Latin American and Caribbean Studies, 27: 53 (2002), pp. 9-34.

${ }^{9}$ I subject this theory to a further test elsewhere through a comparative study of a case where programmatic commitment is absent (AUS in Peru), a case where it is present (AUGE in Chile) and a mixed case (Seguro Popular in Mexico). See Zoila Ponce de Leon, 'Political Parties and Policy Reform: Expansion of Healthcare in Latin America', PhD diss., University of North Carolina at Chapel Hill, 2018.

${ }^{10}$ Levitsky and Cameron, 'Democracy without Parties?'; Mainwaring (ed.), Party Systems in Latin America; Scott Mainwaring and Timothy R. Scully, Building Democratic Institutions: Party Systems in Latin America (Stanford, CA: Stanford University Press, 1995).

${ }^{11}$ Levitsky and Cameron, 'Democracy without Parties?'; Levitsky, 'Peru: The Institutionalization of Politics without Parties'.

${ }^{12}$ Eduardo Dargent, Technocracy and Democracy in Latin America (Cambridge, UK: Cambridge University Press, 2015). 
enjoyed a great degree of autonomy during the 1990s, it decreased in the early 2000s when international financial institutions (IFIs) 'gradually lost interest in health policy reform' ${ }^{13}$ However, during the AUS policy-making process, technocrats from the United States Agency for International Development (USAID) enjoyed a great degree of autonomy. This autonomy allowed them to dominate the policy-making process, which, in the context of a lack of commitment from the main parties, led to the introduction of a poorly specified reform.

\section{Healthcare in Latin America}

A key feature that defines healthcare in Latin America is inequality: between those who use the public health sector's services and those who can afford private services, and also between citizens with formal jobs who have access to a healthcare scheme through salary contributions and those within the informal economy (over 50 per cent of the Latin American population) who are usually unprotected. ${ }^{14}$ Over the last decades, Latin America has witnessed major attempts to tackle these disparities. Reforms seeking expansion of healthcare access have taken place in different countries such as Argentina, Chile, Colombia, Ecuador, Mexico, Venezuela, Peru and Uruguay.

Many of these policies, labelled as 'universal', have become popular among both international organisations, such as the World Health Organization (WHO) and the United Nations (UN), and national governments. ${ }^{15}$ As Juliana Martínez Franzoni and Diego Sánchez-Ancochea point out, these governments call their policies 'universal' because they 'seek to reach everyone, even if they entail unequal benefits. ${ }^{16}$ These reforms have been different: some more expansive than others, with more or less planning behind them, some more sustainable than others.

In order to explain the differences between reforms seeking to expand access to social benefits, an important body of literature has focused on the role of left-wing political parties, arguing that effective expansion is the responsibility of strong leftist parties. ${ }^{17}$ Scholars find parties' ideology to be pertinent to the allocation of attention and public spending towards certain issues, and hence expect the Left to be more inclined to pay attention to and spend on the development of the welfare state. ${ }^{18}$ This literature has neglected a focus on right-wing parties as responsible for policy expansion. Based on this body of research, we should expect the

\footnotetext{
${ }^{13}$ Ibid., p. 135.

${ }^{14} 53.1$ per cent in Latin America and the Caribbean in 2016. See International Labour Organization (ILO), Women and Men in the Informal Economy: A Statistical Picture, third edition (Geneva: ILO, 2018).

${ }^{15} J u l i a n a$ Martínez Franzoni and Diego Sánchez-Ancochea, The Quest for Universal Social Policy in the South: Actors, Ideas and Architectures (Cambridge: Cambridge University Press, 2016).

${ }^{16} \mathrm{Ibid}$., p. 6.

${ }^{17}$ Gøsta Esping-Andersen, The Three Worlds of Welfare Capitalism (Princeton, NJ: Princeton University Press, 1990); Evelyne Huber and John Stephens, Development and Crisis of the Welfare State: Parties and Policies in Global Markets (Chicago, IL: University of Chicago Press, 2010); María Victoria Murillo, 'Partisanship amidst Convergence: The Politics of Labor Reform in Latin America', Comparative Politics, 37: 4 (2005), pp. 441-58; Pribble and Huber, 'Social Policy and Redistribution'.

${ }^{18}$ André Blais, Donald E. Blake and Stéphane Dion, 'Do Parties Make a Difference? A Reappraisal', American Journal of Political Science, 40: 2 (1996), pp. 514-20; Francis Geoffrey Castles, The Impact of Parties: Politics and Policies in Democratic Capitalist States (Beverly Hills, CA: Sage, 1982); Evelyne
} 
development of health reform in countries such as Uruguay and Chile, but be surprised by the same phenomenon in countries like Peru.

In Latin America, we have seen the disappearance of many programmatic political parties and the development of weak, non-programmatic ones. ${ }^{19}$ By the 2000s, Chile and Uruguay were the only remaining countries that had strongly programmatic political parties, whereas parties in Bolivia, Colombia and Peru qualified as weakly programmatic. ${ }^{20}$ Surprisingly, with the exception of Jennifer Pribble, ${ }^{21}$ this phenomenon has been overlooked in terms of policymaking. A significant group of quantitative studies has pointed out the importance of party-system institutionalisation in different regions of the world, ${ }^{22}$ as well as programmatic parties in Latin America, for the quality of policy. ${ }^{23}$ These studies do not differentiate between policy areas; neither do they address how non-programmatic parties affect policy-making. How are reforms adopted in the context of non-programmatic parties? What are the consequences of reform adopted by non-programmatic parties? These are questions that remain unanswered.

Another factor that scholars find to be a determinant of social policy reform is economic development, as wealthier countries have more funds available for social expenditure. ${ }^{24}$ However, countries with the same level of economic development choose different types of social policies, in both high-income and low-income countries. $^{25}$ In Latin America, episodes of social policy expansion have occurred in times of both economic growth and economic crisis, ${ }^{26}$ and improvement of key indicators such as infant mortality can occur independent of economic circumstances. $^{27}$

Literature on democratisation asserts that democracy is beneficial to the expansion of social protection. ${ }^{28}$ By opening a channel to demands from different groups, especially those being excluded from the provision of benefits, democracies respond

Huber and John Stephens, Democracy and the Left: Social Policy and Inequality in Latin America (Chicago, IL: University of Chicago Press, 2012).

${ }^{19}$ Kitschelt et al., Latin American Party Systems; Mainwaring (ed.), Party Systems in Latin America.

${ }^{20}$ Ibid.

${ }^{21}$ Pribble, Welfare and Party Politics.

${ }^{22}$ Carlos Scartascini, Ernesto Stein and Mariano Tommasi, 'Political Institutions, Intertemporal Cooperation, and the Quality of Public Policies', Journal of Applied Economics, 16: 1 (2013), pp. 1-32.

${ }^{23}$ Ernesto Stein and Mariano Tommasi, 'The Institutional Determinants of State Capabilities in Latin America', in François Bourguignon and Boris Pleskovic (eds.), Annual World Bank Conference on Development Economics Regional 2007: Beyond Transition (Washington, DC: World Bank 2007), pp. 193-225.

${ }^{24}$ Alex Segura-Ubiergo, The Political Economy of the Welfare State in Latin America (Cambridge: Cambridge University Press, 2007).

${ }^{25}$ High-income: Esping-Andersen, The Three Worlds; Huber and Stephens, Democracy and the Left. Low-income: Huber and Stephens, Development and Crisis of the Welfare State; Fernando Filgueira, 'Latin American Social States: Critical Junctures and Critical Choices', in Yusuf Bangura (ed.), Democracy and Social Policy (London: Palgrave Macmillan, 2007).

${ }^{26}$ Garay, Social Policy Expansion.

${ }^{27}$ McGuire, Wealth, Health, and Democracy.

${ }^{28}$ Adam Przeworski, Democracy and Development: Political Institutions and Wellbeing in the World 1950-1990 (Cambridge: Cambridge University Press, 2000); Amartya Sen, Development as Freedom (New York: Random House, 1999). 
to the needs of their citizens through pressure. ${ }^{29}$ Along these lines, Candelaria Garay finds that the presence of electoral competition and social mobilisation can explain the expansion of social policy in the region. As Garay points out, in Peru neither electoral competition nor social mobilisation was present. ${ }^{30}$ How can we then explain the development of reform attempting to expand access to healthcare? What explains the reform reaching the agenda?

An important body of literature has focused on the diffusion of policy models to explain the emergence and type of reform, finding that policy reforms can travel from one country to another. ${ }^{31}$ Although, by the late 1990s, IFIs started to lose interest in healthcare policy, ${ }^{32}$ the World Bank as well as the WHO and the Pan American Health Organization (PAHO) were advocating for an expansion of healthcare to excluded segments of the population, thus raising governments' awareness of the need for change. However, as Kurt Weyland asserts, given that a singular model of healthcare reform is extremely rare, diffusion in this area does not arise in the form of policy-makers borrowing models. ${ }^{33}$ International networks' success at influencing policy can be greatly enhanced by the involvement of national bureaucracies, as Christina Ewig's analysis of the development of health policy in Peru shows. ${ }^{34}$ National bureaucrats' participation in what the author calls 'epistemic communities' guarantees bureaucratic commitment to the new models. However, these external models can still lack political commitment, which can be a determinant for the implementation of reform and ultimately for its success.

\section{Theory}

Political parties play key roles in forming democratic governments, organising the work of the legislature and articulating and aggregating citizens' interests and preferences. ${ }^{35}$ Parties also play the role of policy-makers, and different party features can impact the policy-making process at its different stages: (i) agenda-setting, (ii) debate and (iii) implementation. Some studies have pointed out the importance of party-system institutionalisation, ${ }^{36}$ as well as programmatic parties in Latin America for the quality of public policy. ${ }^{37}$ Using large $\mathrm{N}$ quantitative analysis,

\footnotetext{
${ }^{29}$ Stephan Haggard and Robert R. Kaufman, Development, Democracy, and Welfare States: Latin America, East Asia, and Eastern Europe (Princeton, NJ: Princeton University Press, 2008); Filgueira, 'Latin American Social States'; McGuire, Wealth, Health, and Democracy.

${ }^{30}$ Garay, Social Policy Expansion.

${ }^{31}$ Natasha Borges Sugiyama, Diffusion of Good Government: Social Sector Reforms in Brazil (Notre Dame, IN: University of Notre Dame Press, 2013); Kurt Weyland, Bounded Rationality and Policy Diffusion: Social Sector Reform in Latin America (Princeton, NJ: Princeton University Press, 2006).

${ }^{32}$ Dargent, Technocracy and Democracy; Ewig, Second-Wave Neoliberalism.

${ }^{33}$ Weyland, Bounded Rationality.

${ }^{34}$ Ewig, Second-Wave Neoliberalism.

${ }^{35}$ John H. Aldrich, Why Parties?: The Origin and Transformation of Political Parties in America (Chicago, IL: University of Chicago Press, 1995); Mainwaring (ed.), Party Systems in Latin America; Mainwaring and Scully, Building Democratic Institutions; Giovanni Sartori, Parties and Party Systems: A Framework for Analysis (New York: Cambridge University Press, 1976).

${ }^{36}$ Scartascini et al., 'Political Institutions'.

${ }^{37}$ Stein and Tommasi, 'The Institutional Determinants'.
} 
these studies do not look at the process that can explain how non-programmatic parties affect policy-making.

Unlike programmatic parties, non-programmatic parties fail to hold a coherent set of policy programmes. ${ }^{38}$ A vision of how society should be organised, an analysis of what the most pressing problems in a society are, as well as a plan to solve them, are absent for non-programmatic parties. We can distinguish two components in programmatic parties: (i) programmatic unity of its core members and (ii) programmatic appeals to voters. When studying parties as policy-making actors, it is the first component that deserves further evaluation.

Non-programmatic parties do not have core values uniting their leaders. The leaders do not share values that they care about the most and therefore do not unite parties organically. A party can hold an ideological stance on key issues such as a state-run vs. market-led economy, but what determines a party's programmatic commitment is whether a specific policy relates to its core values. If a party lacks core values uniting its members, the party will lack a programmatic commitment to the policy: to the definition of its specifications and to its implementation.

When it comes to healthcare policy, the way political parties approach a specific healthcare issue will depend on how the policy proposal touches upon their core values. How do we explain healthcare reform in the context of parties without core values, which have no commitment to the policy? Actors outside the government, such as think tanks, international organisations or individual technocrats from these groups, will play a key role in this context. Reforms will follow a technocratic path, in which parties disengaged from the definition of policy specifications allow outside actors to dominate the policy-making process.

The policy-making process can be laid out in different stages: (i) agenda-setting, (ii) debate and (iii) implementation. During the agenda-setting stage, recognition of a problem occurs as a 'policy window' opens for those issues that have succeeded in gaining politicians' attention. ${ }^{39}$ Then, the participants inside and outside the government debate the different policy proposals. Finally, after a policy choice is made, implementation follows.

The parties' programmatic commitment to a policy affects the process of policy-making at its different stages. During agenda-setting, it determines whether political parties or actors outside the government place a policy issue on the agenda and lead this process. If parties lack core values uniting their members, a policy issue lacks connection to the parties. In this context, actors outside the government (i.e. think tanks, international organisations, organised interests or individual technocrats from these groups) place the issue on the political agenda. Parties may still preside over or oppose a reform proposal based on factors such as the potential access to new resources at the local level or the command of the party leader. Moreover, popular pressure from social mobilisation

\footnotetext{
${ }^{38}$ Kitschelt et al., Latin American Party Systems; Roberts, 'Party-Society Linkages'.

${ }^{39}$ Bryan D. Jones and Frank R. Baumgartner, The Politics of Attention: How Government Prioritizes Problems (Chicago, IL: University of Chicago Press, 2005); John W. Kingdon, Agendas, Alternatives, and Public Policies (New York: Longman, 2003).
} 
can be an important factor influencing parties to place the issue of reform on the agenda. ${ }^{40}$

During the process of debate, parties' lack of programmatic commitment determines their poor participation in shaping the specifications of the reform proposal. If the policy issue is not related to parties' core values, they do not attempt to shape key specifications such as those regarding implementation and funding. Instead, they leave the process in the hands of individual technocrats. Technocrats without partisan ties are allowed a lot of freedom to introduce poorly specified bills, which politicians do not care to shape, thus generating poor-quality legislation.

Although these bills may be technically effective, they are politically impractical. Technocrats isolated from the political process tend to design policies without considering the politics of implementation. For instance, they may overlook the future need for political support for the financing of the reform and, therefore, neglect to include firmly anchored financing mechanisms in the legislation.

Technocratic actors may also play an active role in the context of programmatic parties, but they are likely to have partisan ties. Martínez Franzoni and Sánchez-Ancochea show that in the case of Costa Rica the presence of experts connected to a programmatic political party in government was highly relevant for the development of successful reform. ${ }^{41}$ In contrast, in the context of nonprogrammatic parties, technocrats lack partisan ties and hence long-term incentives to specify policy proposals given the short-term nature of their influence. The participation of technocrats does not always lead to poorly specified bills, but in the context of parties that lack a programmatic commitment to the policy, there is a widespread lack of commitment. Isolated technocrats lack the political skills and political networks to design legislation that will be successfully implemented and to generate sufficient political support for the reforms to become sustainable.

During implementation, the specifications of the bill shaped during the process of debate will determine the feasibility of the reform as well as the sustainability of the project in the long term. Political actors' lack of programmatic participation in the definition of the bill during the debate stage hinders these same actors' commitment to the implementation of the reform. In such a context, relevant actors in charge of the implementation can end up hindering the reform process. The main repercussion of the lack of programmatic discussion and lack of political commitment to the reform is a poorly executed implementation. When the different political parties do not participate in the process of debate, neglecting to define policy specifications, there is no political commitment to the reform and its implementation.

\section{Research Design}

The dependent variable I seek to explain is the quality of reform enacted and implemented. I identify two types of policy specifications that policy-makers define during the process of debate in Congress, which are crucial for the effective implementation

\footnotetext{
${ }^{40}$ Fairfield and Garay, 'Redistribution under the Right'; Garay, Social Policy Expansion; Christopher L. Gibson, Movement-Driven Development: The Politics of Health and Democracy in Brazil (Stanford, CA: Stanford University Press, 2019).

${ }^{41}$ Martínez Franzoni and Sánchez-Ancochea, The Quest for Universal Social Policy.
} 
of the reform if approved: (i) sources of funding for the reform's implementation and (ii) an infrastructure assessment to establish the gap that the government needs to cover before the reform's implementation. These two key policy specifications determine the quality and feasibility of the reform. They determine whether the implementation of the reform actually leads to better access to healthcare rather than just an increase in formal coverage.

My research shifts the focus away from social-spending patterns and towards the process behind the formation of policy and how it determines the quality of legislation and implementation. Studies that focus on budgets, and not necessarily on the quality of the policy approved, ${ }^{42}$ do not address the importance of agency from legislators and other policy-makers in crafting the different specifications of a policy.

I focus on the Peruvian reform approved in 2009, AUS, which was debated in Congress during García's last term (2006-11). Although called 'universal', this policy did not aim to provide the same entitlements to the whole population, but instead provided what Martínez Franzoni and Sánchez-Ancochea refer to as an 'instrument' to achieve universalism. ${ }^{43}$ The goal was for AUS to help achieve widespread insurance coverage of the Peruvian population and expand access to healthcare.

Leftist parties in Peru were extremely weak during the AUS policy-making process. Furthermore, the Peruvian reform was developed under a party system that lacked institutionalisation, and political parties that were far from programmatic. The party in government, APRA, had originated as a left-wing party in the 1920s and then shifted towards the Right in the subsequent decades, which was particularly clear during García's second term. Categorised as a 'populist machine', APRA 'largely abandon[ed] their redistributive commitments' during García's second term. ${ }^{44}$ As opposition, APRA had the left-wing coalition between Unión por el Perú (Union for Peru, UPP) and the Partido Nacionalista Peruano (Peruvian Nationalist Party, PNP), as well as the right-wing coalition Unidad Nacional (National Unity). ${ }^{45}$ Peruvian parties are characterised by the use of charismatic and clientelistic appeals to attract support from the population rather than policy programmes, as well as by their lack of institutionalisation. ${ }^{46}$ How are

\footnotetext{
${ }^{42}$ Wendy Hunter and David S. Brown, 'Democracy and Social Spending in Latin America, 19801992', American Political Science Review, 93: 4 (1998), pp. 779-90; Evelyne Huber, Thomas Mustillo and John D. Stephens, 'Politics and Social Spending in Latin America', Journal of Politics, 70: 2 (2008), pp. 420-36; Robert R. Kaufman and Alex Segura-Ubiergo, 'Globalization, Domestic Politics, and Social Spending in Latin America: A Time-Series Cross-Section Analysis 1973-97', World Politics, 53: 4 (2001), pp. 553-87; Nita Rudra, Globalization and the Race to the Bottom in Developing Countries (Cambridge: Cambridge University, 2008); Alex Segura-Ubiergo, The Political Economy of the Welfare State.

${ }^{43}$ Martínez Franzoni and Sánchez-Ancochea, The Quest for Universal Social Policy.

${ }^{44}$ Levitsky and Roberts (eds.), The Resurgence of the Latin American Left, p. 5.

${ }^{45}$ The UPP-PNP coalition was formed to support the presidential candidacy of Ollanta Humala, who lost the election to García in 2006. Unidad Nacional formed before the 2001 presidential election and presented Lourdes Flores as its candidate; the Partido Popular Cristiano (Christian Popular Party), Partido Solidaridad Nacional (National Solidarity) and Renovación Nacional (National Renewal) composed it.

${ }^{46}$ Maxwell A. Cameron, 'The Left Turn that Wasn't'; Kitschelt et al., Latin American Party Systems; Steven Levitsky, 'Peru: The Institutionalization of Politics without Parties'; Levitsky and Cameron, 'Democracy without Parties?'; Tanaka, 'Perú, 1980-2000'.
} 
reforms adopted in the context of non-programmatic parties? What are the consequences of reform adopted by non-programmatic parties?

I process-traced the policy-making of AUS in Peru, identifying the main actors placing the issue on the agenda and the policy specifications regarding funding and implementation that were shaped during debate. I conducted over 60 in-depth, semi-structured interviews in Lima, Peru, with key actors from inside and outside the government, including former health ministers, legislators and party leaders; technocrats who worked for the Ministerio de Salud (Ministry of Health, MINSA) and the Ministerio de Economía y Finanzas (Ministry of Economy and Finance, MEF); representatives from private insurance and private provider companies, from professional associations and international organisations; and policy experts. ${ }^{47}$ I selected interviewees based on their participation in the promotion, debate and design of the reform, also considering how a potential reform could affect their interests.

I also collected evidence with archival research from the legislatures and the executives as well as official statistics on the reform's implementation. I triangulated in-depth information from interviews with transcripts of all the debates on the reform that took place in the committees and on the floor of Congress. I identified the actors participating in the debates, as well as the arguments they used in support of or against the proposals. I also accessed official documentation from meetings carried out in MINSA and MEF. This was important to establish a general timeline of the reform and to cross-check the accuracy of accounts from interviewees.

In order to measure the presence of core values for the Peruvian parties, I look at the parties' positions on whether an economy should be regulated by the state or the market, which can show the level of agreement present among party leaders. I also look at their positions on three other policy issues (see Table A.2.1 in the online Appendix). This data was collected by the Parliamentary Elites in Latin America (PELA) study, a series of surveys conducted among Peruvian members of parliament at the end of $2006 .^{48}$

\section{The Peruvian Reform}

In the 2000s, Peru, like many countries in the region, had a fragmented health system. By 2007, those with formal jobs were part of the social-security system through Seguro Social de Salud del Perú (Peruvian Social Health Insurance, EsSalud) (20 per cent), while the rest of the population either bought a private insurance ( 3 per cent), affiliated to a special scheme for the poor (16.9 per cent) or remained unprotected (58 per cent). ${ }^{49}$ This system, characterised by fragmentation, was the product of a decade of market-oriented reforms that 'epistemic communities' built amid the Peruvian health bureaucracy and IFIs pushed for. ${ }^{50}$ Given the fragmentation and

\footnotetext{
${ }^{47}$ For a list of interviews, see online Appendix, available at doi.org/10.1017/S0022216X21000493 under the 'Supplementary materials' tab.

${ }^{48}$ The Observatorio de Élites Parlamentarias de América Latina/ Parliamentary Elites in Latin America (PELA) data is available at https://oir.org.es/pela/, last access 16 June 2021.

${ }^{49}$ The remaining 2 per cent was affiliated to the military and police health system. Ministerio de Salud (MINSA), Cuentas nacionales de salud, Perú 1995-2012 (Lima: MINSA, 2015).

${ }^{50}$ Ewig, Second-Wave Neoliberalism.
} 
the sector's lack of resources, a reform that would bring more equity into the system had been a latent issue in the country. By the early 2000s, IFIs' degree of interest and influence had decreased, and so had the autonomy of the technocrats linked to them. ${ }^{51}$ However, an actor that gained importance during that time was USAID.

AUS had the goal of achieving, in the long term, universal insurance coverage of the population, and gradually expanding coverage of health conditions by guaranteeing access to treatment for a set of diseases, hence levelling the benefits across insurance schemes. In Peru the health-reform policy-making process lacked the participation and commitment of the country's main political parties. One of the main repercussions of this was that parties did not lead the Peruvian reform's agenda-setting process; instead, it was an actor outside the government that placed the issue onto the political agenda: USAID.

At the end of Alberto Fujimori's second term (1995-2000), MINSA implemented, for the first time, schemes for people who did not have formal employment: (i) Seguro Escolar Gratuito (Free School Insurance, SEG), created in 1997 to give access to health services to children between the ages of three and 17 who were registered in public schools; and (ii) Seguro Materno Infantil (Maternity and Child Insurance, SMI), created in 1998 for women going through pregnancy and the post-partum period as well as children below four years of age. ${ }^{52}$ These two programmes included a very restrictive set of benefits for the most prevalent pathologies among the target populations. ${ }^{53}$

During the short interim government of Valentín Paniagua (November 2000July 2001) after Fujimori's fall, Health Minister Eduardo Pretell and his team, with the help of the PAHO, put together a proposal that would extend social security to informal workers who did not have access to health services through EsSalud. The goal was to integrate MINSA's provision system with EsSalud. They proposed starting with a basic set of benefits that every Peruvian could have access to, although EsSalud affiliates would maintain their additional benefits. However, the Alejandro Toledo government (2001-6) dismissed this proposal. ${ }^{54}$ Instead, in September 2001, they decided to integrate the two state-insurance programmes, SEG and SMI, into the new Seguro Integral de Salud (Comprehensive Health Insurance, SIS), maintaining a scheme of specific benefits plans for each target population. Additionally, every poor child under 18 could have access to SIS. By 2005 , every poor citizen could affiliate to SIS. ${ }^{55}$

\footnotetext{
${ }^{51}$ Dargent, Technocracy and Democracy.

${ }^{52}$ Miguel Jaramillo and Sandro Parodi, 'El Seguro Escolar Gratuito y el Seguro Materno Infantil: Análisis de su incidencia e impacto sobre el acceso a los servicios de salud y sobre la equidad en el acceso', Grupo de Análisis para el Desarrollo (GRADE) Working Paper No. 46, 2004.

${ }^{53}$ Although they were called 'insurance', those who were affiliated did not have to pay a premium, it was completely free.

${ }^{54}$ Author interviews with Ariel Frisancho (MINSA director 1995-2000, ForoSalud national coordinator 2011-13), Lima, 9 Dec. 2015; Juan Arroyo (ForoSalud national coordinator 2002-4, MINSA vice-minister 2017), Lima, 10 Feb. 2016; anonymous interviewee (former member of the USAID Health Office in Lima); Víctor Carrasco (Professor at Universidad Peruana Cayetano Heredia), Lima, 13 Nov. 2015.

${ }^{55}$ See timeline in the online Appendix, available at doi.org/10.1017/S0022216X21000493 under the 'Supplementary materials' tab.
} 
The main problems SIS faced were related to its payment system based on refunds: MINSA refunded hospitals, the only place where SIS affiliates could get attention, only after they provided the services. These refunds took months, and in many cases there were huge debts owed to the hospitals. As a consequence, in some hospitals, personnel started to make it very difficult for SIS patients to get attention as well as obstructing the process of affiliation to SIS.

\section{Agenda-Setting, or Where Did the AUS Project Come From?}

Political parties did not lead the Peruvian reform agenda-setting process. They lacked core ideological values uniting their members. Consequently, they lacked connection to the issue of healthcare reform. The positions of members of parliament representing the different parties, on whether an economy should be regulated by the state or the market, are indicative of the parties' consensuses on these values.

As Table 1 shows, there was a lot of dispersion within the different parties. ${ }^{56}$ In the case of the party in power, APRA, the importance of a market-led economy was not a core commitment, although it was important for some of its members. The main value that brought unity within APRA was the allegiance to its leader García (and its founder Víctor Raúl Haya de la Torre) and not programmatic values. In the case of UPP-PNP, there was a lot of variation across party members regarding different values such as equality, social inclusion or a state- vs. market-led economy. This electoral coalition, which managed to gather over 21 per cent of the popular vote and secure 45 of the 120 seats in the unicameral Congress, was not united by programmatic values but rather by electoral prospects. The right-wing coalition Unidad Nacional, the third force in Congress, was also united for electoral reasons instead of around core programmatic values. By 2008, both coalitions had split.

In such a context, an outside actor, Partners for Health Reformplus (PHRplus) - a five-year project (2000-5) funded by USAID in Peru - was responsible for the introduction of AUS onto the political agenda. ${ }^{57}$ In 2005, PHRplus convened a meeting of representatives on the issue of health from all political parties and produced the 'Agreement of Political Parties on Health'. The continuation project of PHRplus, called Promoviendo Alianzas y Estrategias (Promoting Alliances and Strategies, PRAES), presented the agreement to the public in January 2006. One of the main focuses of these meetings was the promotion of the AUS policy via a fragmented system, and so it was listed as a key priority in the final agreement. Nearly all the party representatives that participated in the meetings signed the agreement, with the exception of the left-wing UPP (recently allied with PNP).

\footnotetext{
${ }^{56}$ Table A.2.1 in the online Appendix, available at doi.org/10.1017/S0022216X21000493 under the 'Supplementary materials' tab, shows the positions of the parties for a further three policy issues (price controls, subsidised housing, free university education), on which the Peruvian parties are equally dispersed.

${ }^{57}$ Author interviews with, among others, Oscar Ugarte (former PRAES consultant, health minister 2008-11), Lima, 27 Nov. 2015; Arturo Granados (PHRplus, PRAES, and PolSalud consultant 2003-12, MINSA director 2012-16), Lima, 28 Jan. 2016; anonymous interviewee; Jorge Ruiz (PPC advisor, CEO of the Stella Maris Clinic and board member of the Private Clinics' Association of Peru 2002-12), Lima, 25 Jan. 2016; Ada Pastor (PHRplus and PRAES consultant 2003-8, MINSA director 2012), Lima, 22 Jan. 2016; David Tejada (PNP advisor 2006-11), Lima, 28 Jan. 2016; Luis Wilson (APRA congressman 2006-11), Lima, 13 Feb. 2016.
} 
Table 1. Political Parties' Positions on a State-Led vs. Market-Led Economy

\begin{tabular}{lcccccc}
\hline Political parties & $\begin{array}{c}\text { State } \\
(1)\end{array}$ & 2 & 3 & 4 & $\begin{array}{c}\text { Market } \\
(5)\end{array}$ & $\begin{array}{c}\text { Standard } \\
\text { deviation }\end{array}$ \\
\hline APRA & 0 & 7.1 & 60.7 & 17.9 & 14.3 & 0.82 \\
Unidad Nacional & 7.1 & 7.1 & 21.4 & 42.9 & 21.4 & 1.11 \\
UPP-PNP & 17.1 & 17.1 & 48.6 & 5.7 & 11.4 & 1.15 \\
\hline
\end{tabular}

Source: Author's elaboration based on data from the Parliamentary Elites in Latin America (PELA) study, 2006.

According to its representative, it did not sign because AUS 'saw health as a commodity and not as a right'. ${ }^{58}$

PHRplus had worked on AUS since 2004, planning benefits and health-services guarantees to which those insured would have access. In an interview, a former PRAES member pointed out that it was important for the project 'to have a political consensus to back the AUS policy'. ${ }^{59}$ A member of the USAID Health Office in Peru during that time noted that the agreement was important for USAID, as it was a highlighted point when asking for funds from its donors. AUS became a flagship project for USAID in Peru.

AUS would provide coverage to the 50 per cent of the population that was uninsured, through the expansion of the healthcare scheme for the poor (SIS). SIS would expand in order to cover informal workers regardless of their income. Further, through the Plan Esencial de Aseguramiento en Salud (Essential Health Insurance Plan, PEAS) - a package of benefits and health-services guarantees the coverage of health conditions for those affiliated to SIS would gradually equate that provided by the social-security system. PEAS would be revised every two years.

Motivated by the discussions fostered by the USAID projects, between December 2006 and April 2007, seven bills were introduced to Congress. ${ }^{60}$ Even though different parties introduced bills on the issue, these bills did not have their origins in debates within their parties. In the case of APRA and Unidad Nacional, the content of these bills was a product of a few advisors and consultants from the USAID project and the private sector.

The first bill introduced to Congress came from the right-wing coalition Unidad Nacional. The coalition had two main advisors on health at the time: Jorge Ruiz, who was also CEO of an important private clinic in Lima (Stella Maris Clinic), as well as a board member of the Asociación de Clínicas Particulares del Perú (Private Clinics' Association of Peru) (2002-12); and Alberto Valenzuela, who was the technical director of the same association. Both advisors noted that in 2005 they 'discussed some ideas with' then leader of PRAES Midori de Habich (who later became health minister). Valenzuela also noted that they asked PRAES' members for help in crafting the bill that they handed to the Unidad Nacional coalition in Congress. ${ }^{61}$ A key member of PRAES, Oscar Ugarte (who

\footnotetext{
${ }^{58}$ Author interview with David Tejada.

${ }^{59}$ Author interview with Arturo Granados.

${ }^{60}$ Political parties as well as individual legislators can send bills to Congress.

${ }^{61}$ It was also the job of this second advisor to gather the signatures of all the coalition members on the bill before it was introduced.
} 
also became health minister), noted: 'AUS was proposed by PRAES and then taken by Unidad Nacional and APRA. ${ }^{62}$ De Habich, however, stated she did not remember whether the bill for Unidad Nacional was crafted within PRAES, although 'it is possible that PRAES had put together a draft of AUS and shared it with all the participants, ${ }^{63}$ as it was a rule of the group to not help a specific party. ${ }^{64}$

The right-wing APRA in government also introduced a bill which proposed a package that would establish the benefits and health-services guarantees that all insurance institutions, public and private, would be bound to fulfil (called PEAS). PEAS was a product of the USAID-funded projects, which had worked on it since $2004 .^{65} \mathrm{~A}$ month later, APRA introduced a second bill, which was very similar to Unidad Nacional's bill. The main APRA advisor on health issues claimed that it was due to a dialogue that existed with Unidad Nacional advisors, who became of 'great technical and political support. ${ }^{66}$

The opposition also introduced bills on the issue. The main advisor of the left-wing coalition UPP-PNP (the only representative that did not sign the USAID agreement back in 2005) noted that the proposal was unviable given the sceptical position most legislators had towards a universal social-security system that would put an end to the fragmented system. Indeed, the idea of merging the social-security system (EsSalud) with the insurance system for the poor (SIS) was highly controversial, as its opponents argued that EsSalud would not accept its contributions being used to subsidise services for anybody else. The party decided to send the bill, even though it knew it had no chance of going forward. Just a month later, another congresswoman sent a new bill, although, as one of the health advisors of the coalition noted, without prior discussion and hence without the support of the coalition members. The third bill UPP-PNP presented 'jumped into the AUS boat' (in the words of the coalition's main health advisor), ${ }^{67}$ as it understood its original idea was not going to get anywhere.

Then president of the Health Committee in Congress, Luis Wilson (APRA), formed a working group on AUS in July 2008. The different parties' health advisors participated, as well as PRAES members Aníbal Velásquez (who also became health minister) and Ugarte. Wilson's main advisor noted that Wilson asked for help from PRAES and that 'PRAES already had an outline of how AUS should look'. ${ }^{68}$ The

\footnotetext{
${ }^{62}$ Author interview with Oscar Ugarte.

${ }^{63}$ Author interview with Midori de Habich (former health minister of Peru; former head of PHRplus, PRAES and PolSalud), Lima, 11 Dec. 2015.

${ }^{64}$ For a graphical depiction of the connections between the different actors involved in the policy-making process of AUS, see Figure A.4.1 in the online Appendix, available at doi.org/10.1017/S0022216X21000493 under the 'Supplementary materials' tab.

${ }^{65}$ Author interviews with, among others, José del Carmen (health vice-minister 2005-6 and 2012-14), Lima, 17 Feb. 2016; César Chanamé (EsSalud manager 2006-11, health vice-minister 2015), Lima, 10 Feb. 2016; Melitón Arce (chief MINSA advisor 2006-7, health vice-minister 2007-10), Lima, 6 Feb. 2016; Arturo Granados; anonymous interviewee; Paulina Giusti (health vice-minister 2014-15, MINSA advisor 2005-7), Lima, 10 Dec. 2015.

${ }^{66}$ Author interview with Carlos Ponce (APRA/Wilson advisor 2006-11, MINSA advisor 2015), Lima, 18 Dec. 2015.

${ }^{67}$ Author interview with Víctor García (former advisor to UPP Congressman Francisco Escudero, former MINSA advisor), Lima, 15 Dec. 2015.

${ }^{68}$ Author interview with Carlos Ponce.
} 
committee discussed AUS for the first time in September 2008. At this point, according to accounts from Wilson and other APRA members, President García began to show interest in the passage of AUS, which would help to portray himself as a more inclusive president. ${ }^{69}$

The evidence shows that members of the USAID projects had been working on AUS since 2004, before the bills were presented to Congress in 2006. They met parties' representatives and their experts heavily influenced the AUS bills Unidad Nacional and APRA introduced. Within USAID, AUS was regarded as a major success as they decided important details of the reform. They successfully prevented the expansion of social security and instead pushed for the continuation of a fragmented system. Moreover, three of their consultants went on to become health minister: Ugarte (2008-11), de Habich (2012-14) and Velásquez (2014-16). In the context of non-programmatic parties, external actors determine the introduction of reforms onto the agenda.

It is important to note the participation of the private-provision sector during this stage of the policy-making process. Unidad Nacional advisor Ruiz, a representative of the Private Clinics' Association of Peru, was in charge of crafting the bill Unidad Nacional introduced in Congress. This bill proposed a system that maintained the private sector's independence and security. Together with the USAID projects, the private sector was able to prevent a unified system that could limit its importance.

Political parties did not lead the Peruvian reform's agenda-setting process. The parties lacked core ideological values uniting their members. Consequently, they lacked connection to the prospect of healthcare reform. Although different parties introduced bills on the issue, in the case of APRA and Unidad Nacional, a few actors from USAID and the private sector crafted these bills. The leftist coalition UPP-PNP initially introduced a bill opposing AUS and favouring the expansion of social security. However, the coalition later supported the continuation of the fragmented system via AUS. In the context of non-programmatic parties lacking commitment to the reform, an external actor in the form of the USAID-funded projects was a determinant factor in the introduction of the reform onto the agenda.

\section{Debate}

The process of AUS debate in Peru lacked the participation of the main political parties. The Peruvian parties lacked core values that could connect to the issue of healthcare reform and therefore had no programmatic commitment to the reform. These parties did not shape the specifications of the policy and approved a law that lacked specifications regarding the necessary funding to be implemented as well as political commitment. AUS promoters preferred to avoid discussions on infrastructure and funding because these issues were considered controversial and could put at risk the passage of the law. Individual technocrats without partisan ties filled the void left by the parties' lack of participation.

\footnotetext{
${ }^{69}$ García's choice to appoint Oscar Ugarte, a USAID consultant but also a known member of a regional left-wing party, can also be seen as linked to this intention.
} 
In September 2008, the Health Committee in Congress discussed AUS for the first time. The right-wing coalition Unidad Nacional introduced one of the first bills (and the final law Congress passed was very similar to this bill). However, as the transcriptions of the debates show, Unidad Nacional's representatives in Congress rarely participated in the debates within the Health Committee and on the floor. As Unidad Nacional advisors Ruiz and Valenzuela (who were also private-sector representatives) commented in my interviews, they had to gather the support of the Unidad Nacional legislators.

The left-wing coalition UPP-PNP failed to push for better policy specifications during the debate. For APRA and Unidad Nacional members, the universalisation of social security promoted a utopian discourse of 'everything for everybody'. In the end, UPP traded its vote. UPP legislators were not interested in passing a proposal that could be implemented. As a UPP advisor put it, it was a clear indication of the party's lack of maturation and the main reason why it was not strong enough to oppose AUS in Congress. In my interviews, the main advisors from APRA, Unidad Nacional, UPP and PNP noted that most congressmen, as well as their staff, lacked health policy expertise and did not understand the projects that well. This is symptomatic of the lack of connection that the healthcare reform had to the core values of these parties.

At the Health Committee, two main advisors were in charge of the AUS working group; one of them was Velásquez, from PRAES. Wilson (APRA), then president of the committee, noted that the point of these meetings was to generate consensus between the different actors involved. However, those who represented the opposition to AUS disagreed and argued that the meetings were mainly 'monologues of PRAES people ... they were not debates but presentations. ${ }^{70}$

After holding nine hearings between September and December 2008, the committee gave its verdict (dictamen) on AUS. During the meetings, the funding of AUS failed to become the centre of discussion. AUS was going to require a good amount of funding for two main areas: strengthening the supply side (mainly infrastructure and human resources) and financing the demand (the state would cover the services for poor people completely, and partially for those with some acquisitive power). Surprisingly, very little debate went into how to fund this proposal.

In the executive, the issue of funding did gather more attention. According to the health vice-minister's advisor, who was in charge of the meetings between MINSA and MEF, 'the main question MEF had was how are you going to do this? But that had not yet been designed. [MEF] wanted concrete numbers ... There was no financing plan. ${ }^{71}$ The advisor also noted that the agreement they reached was that 'MINSA would make do with what they were given' ${ }^{72}$ In personal interviews, both the vice-minister and minister of health at the time agreed that they settled for this agreement and hoped to obtain resources in the future.

If the AUS bill did not specify the number of monetary resources needed, neither did it specify the sources. The bill only mentioned that the funds would come

\footnotetext{
${ }^{70}$ Author interview with Víctor Carrasco.

${ }^{71}$ Author interview with Augusto Portocarrero (former director of the Planning and Budget Division at MINSA), Lima, 8 Jan. 2016.

${ }^{72}$ Ibid.
} 
from general taxes, and APRA legislators emphasised that the executive would be in charge of determining the details once AUS was approved. Moreover, several AUS promoters emphasised that engaging in a discussion about funding and its sources was going to put at risk the passage of the law. The health minister at the time, as well as Unidad Nacional and APRA legislators and advisors, noted that the context of consensus had to be used to launch AUS, even though that meant not having secure funding. ${ }^{73}$ During a presentation at a Health Committee session, the president of the Asociación Nacional de Médicos del MINSA (National Association of MINSA Doctors) criticised the lack of discussion regarding sources of funding for the reform, and hence its sustainability over time. He stated that 'there cannot be any significant and substantive change without policies made to resolve the situation of human resources', and that health policies in Peru should not be 'mere demagogic actions that lead nowhere. ${ }^{74}$

An issue that gathered more attention was the role of the private sector. The opposition to AUS claimed that the reform was going to privatise the health system by bringing more business to the private sector. Private providers saw themselves highly benefitting from AUS through the sale of health services to the public sector. The Private Clinics' Association of Peru did not send a representative to the committee, but it already had two of its members as key actors in the process since its origins: Ruiz, board member of the association and CEO of one of the most important clinics in Lima, as well as Valenzuela, technical director of the association, both of whom were also Unidad Nacional advisors.

The Asociación Peruana de Empresas de Seguros (Peruvian Association of Insurance Companies) sent a formal letter to the committee when the committee had already stated its verdict. The association asked to participate in the Superintendencia Nacional de Aseguramiento en Salud (National Superintendency of Health Insurance, SUNASA), the entity that would be in charge of monitoring the implementation of AUS. Then technical director of the association noted that a concern for them was that the plans that private insurances already offered would not necessarily consider all the health conditions and benefits established in the reform. ${ }^{75}$

Exactly six days after the committee in Congress had given its verdict, the executive sent a bill to Congress. It was nearly identical to the committee's verdict. According to then Health Minister Ugarte, this bill was made in dialogue with some legislators' advisors as well as with PRAES leader de Habich. The president of the committee noted that it was important that the executive sent this bill to show its political support for the project. ${ }^{76}$ Only two points differentiated this bill from the committee's verdict: (i) it gave SUNASA sanctioning powers and

\footnotetext{
${ }^{73}$ Author interviews with, among others, Oscar Ugarte; Walter Menchola (Unidad Nacional congressman 2006-11), Lima, 28 Jan. 2016; Carlos Ponce; Alberto Valenzuela (Unidad Nacional advisor, technical director of the Private Clinics' Association of Peru 2008-10, MINSA advisor 2015-16), Lima, 18 Nov. 2015.

${ }^{74}$ Dr Leoncio Díaz (president of the Asociación Nacional de Médicos del MINSA), speaking at the Health Committee meeting, Lima, 10 Sept. 2008.

${ }^{75}$ For instance, including some psychiatric services was a concern, as neither private clinics nor public hospitals could provide the required services.

${ }^{76}$ Author interview with Luis Wilson. President García started referring to AUS in public as one of the main promises of his government.
} 
(ii) it stated that MINSA would establish an implementing body during the first two years after the passage of the bill.

Congress voted on AUS in March 2009. The law passed with 59 votes in favour; surprisingly, 14 of those votes came from left-wing party UPP, one of the parties that had opposed AUS. ${ }^{77}$ The health minister at the time noted that 'there was a political convincing of UPP' ${ }^{78}$ Then advisor to Congressman Francisco Escudero (UPP) explained that 'APRA negotiated with them'. Wilson's advisor noted that they agreed with Escudero on UPP voting in favour of AUS and then APRA voting in favour of a law Escudero had been trying to pass for a while. ${ }^{79}$ This was not a bad offer as APRA had the larger number of seats in Congress (after PNP and UPP split). Right after the passage of AUS, the discussion of Escudero's bill was included in the agenda 'with priority' and approved some months later with the votes of all APRA legislators.

The process of AUS debate was not very open. As Congressman Walter Menchola (Unidad Nacional), a member of the Health Committee, commented, 'the script was already written, there was not much to discuss' ${ }^{80}$ If we go over the AUS policy-making process, from agenda-setting to debate, there was a very limited group of people participating, who rotated among MINSA, the USAID-funded projects and the private sector. The evidence shows that there was no real commitment to make the debate process a participatory one. An excerpt of my conversation with the main committee advisor at that time might be indicative of the process: 'I have to admit that I was a little bit of a dictator ... "Do you like it [a part of the AUS bill]? No? I will include it anyway." Otherwise, it did not move forward. ${ }^{81}$

Given the Peruvian parties' lack of core values, they lacked connection to the policy and did not attempt to shape the specifications of the reform. This defined both the process of debate as well as the content of the law. Approved in 2009, the law was highly similar to the first bill Unidad Nacional introduced in 2006. The parties in Congress were not part of an exhaustive process of debate. Instead, members tried to avoid the discussion of many important issues such as funding, the feasibility of the project given the shortage of human resources and infrastructure, as well as its sustainability. This lack of commitment from the most relevant political actors proved to be costly during implementation.

Technocrats filled the void that the parties' lack of participation left in Peru, becoming the protagonists of the process of AUS debate. A key technocrat during the AUS debate was former PRAES consultant and then Health Minister Ugarte. Even though the issue of reform was already on the agenda before he became head of MINSA, the process of debate accelerated with his arrival and he acted as mediator between the executive and legislature. PRAES provided logistical resources throughout the process of debate. It not only sent a consultant

\footnotetext{
${ }^{77} \mathrm{PNP}$ remained firm in its position that AUS was only going to benefit the private sector and voted against it.

${ }^{78}$ Author interview with Oscar Ugarte.

${ }^{79}$ Author interviews with Víctor García (UPP/Escudero advisor 2006-10, MINSA advisor 2010-11), Lima, 15 Dec. 2015; and Carlos Ponce.

${ }^{80}$ Author interview with Walter Menchola.

${ }^{81}$ Author interview with Carlos Ponce.
} 
(Velásquez) to the committee in Congress, but also organised meetings outside Congress. As confirmed by the leader of the USAID-funded project, de Habich, PRAES was in charge of 'synthesising differences and similarities [of the bills] at the request of Wilson, president of the committee. This work led to the opinion adopted by this committee. ${ }^{82}$

These technocrats did not have ties to the political parties in charge of the reform's debate. Given the short-term nature of their influence, these technocrats did not commit to crafting a bill with clear specifications regarding the funding and infrastructure needed for the reform to be implemented. When asked about this lack of key specifications, different technocrats noted that they were unnecessary at that point. Moreover, that the next government should be in charge of crafting them, and that it was easier not to include them.

A Congress formed by non-programmatic parties approved a law that lacked the necessary funding to be implemented. AUS promoters preferred to avoid discussions on infrastructure and funding that could put at risk the passage of the law. As the main Health Committee advisor put it, this followed 'the norm that "big policies" are not approved in Congress, but "small" ones that are easy to understand [are approved]'. ${ }^{83}$ This process had a high cost.

\section{Implementation}

The implementation of the Peruvian health reform increased the amount of people with formal insurance coverage. Whereas 42 per cent of the population was insured in 2007,78 per cent had insurance by $2019 .{ }^{84}$ We must be cautious in considering an increase in formal coverage an indicator of the reform's success since the constraints on effective access for people covered 'on paper' hindered progress. Ultimately, the goal of AUS was to achieve universal insurance coverage in order to improve the access to services not covered by social security. Instead, increased formal coverage was accompanied by a shortage of the required resources (infrastructure and human resources) to provide services. Although the reform fostered an increase in state funding for health, this funding has been inconsistent. The lack of commitment to the policy from non-programmatic political parties led to a poorly specified legislation and a deficient implementation, ultimately contributing to the shortage in effective access to healthcare for the population.

AUS passed a vote in Congress in March 2009. A special commission within MINSA, aided by the USAID-funded project PRAES, crafted the Plan Nacional Concertado (National Implementation Plan) in January 2009. There was a set of benefits and health-services guarantees that all health-insurance institutions (public and private) would be bound to fulfil (called PEAS). PEAS considered 140 illnesses for which timely and quality service had to be guaranteed, and it would be revised every two years.

\footnotetext{
${ }^{82}$ Author interview with Midori de Habich.

${ }^{83}$ Author interview with Carlos Ponce.

${ }^{84}$ The 2007 statistic comes from Instituto Nacional de Estadística e Informática (INEI), Informe técnico: condiciones de vida en el Perú (Lima: INEI, 2015). The 2019 statistic comes from INEI, Informe técnico: condiciones de vida en el Perú (Lima: INEI, 2020).
} 
When asked about how ambitious the package was, given the shortage of infrastructure and human resources in the public system, the PRAES member in charge of the PEAS design argued that infrastructure could be strengthened later and that 'to pose that a plan should exist after the [infrastructure] conditions exist delays the process' ${ }^{85}$ Indeed, MINSA began implementing AUS in some areas of Peru without the necessary infrastructure and human resources. The Implementation Plan established that AUS would start in seven pilot areas (which had between 54 and 84 per cent poverty). This started in December 2009 and had to guarantee treatment for 34 illnesses. Another USAID-funded project called HS2020 was in charge of the implementation of PEAS in these pilot areas. At the beginning of 2010, Lima and Callao were included as AUS pilot areas, even though they did not fulfil the condition of having a large poor population. According to then health viceminister, an APRA member close to President García, the president decided that these two regions had to be included, 'otherwise nobody was going to see the results of AUS, ${ }^{86}$ The shortage of infrastructure and human resources, which was not a topic of discussion during the agenda-setting process and debate of the reform, was a major problem.

During the AUS debate, congressmen from non-programmatic parties, who were disengaged from the process, and technocrats from the USAID-funded projects and the private sector avoided a discussion regarding infrastructure. Plans to strengthen the infrastructure of hospitals and health centres and overcome the shortage of doctors, nurses and other health personnel never emerged. How to fund the reform was never part of the debate either. These policy specifications were necessary for AUS to become a reality, not just in terms of formal insurance coverage but also in terms of actual delivery of healthcare services.

President García's term ended in 2011 with a mediocre implementation of AUS in the pilot regions. A lack of infrastructure and a shortage of human resources got in the way, and there were problems that could not be solved without a necessary injection of funding. The process of AUS debate produced a law that lacked the necessary funding for implementation. During the first years of the reform, the funding assigned to the public healthcare scheme covering those outside the socialsecurity system (SIS) did not see significant changes, as shown in Figure 1. The budget saw reductions in 2016, 2017 and 2019. AUS is a policy without the necessary funding.

President Ollanta Humala (2011-16) was the leader of the only party (PNP) that voted against AUS. In July 2012, de Habich, former leader of the USAID-funded projects, who had been actively involved in the agenda-setting and debate of AUS, became health minister. MINSA started the implementation of AUS across the whole country. ${ }^{87}$ One of the first steps was implementing a prospective type of payment for the services delivered to the affiliates. By the end of 2012, SIS, the financial institution in charge, was making trimestral monetary transfers to

\footnotetext{
${ }^{85}$ Author interview with Alfredo Sobrevilla (PolSalud team leader 2012-15, PHRplus and PRAES consultant), Lima, 19 Nov. 2015.

${ }^{86}$ Author interview with Melitón Arce.

${ }^{87}$ According to former Health Minister Ugarte and other interviewees, de Habich convinced First Lady Nadine Heredia of the importance of continuing with AUS. Heredia was a powerful actor during Humala's government.
} 


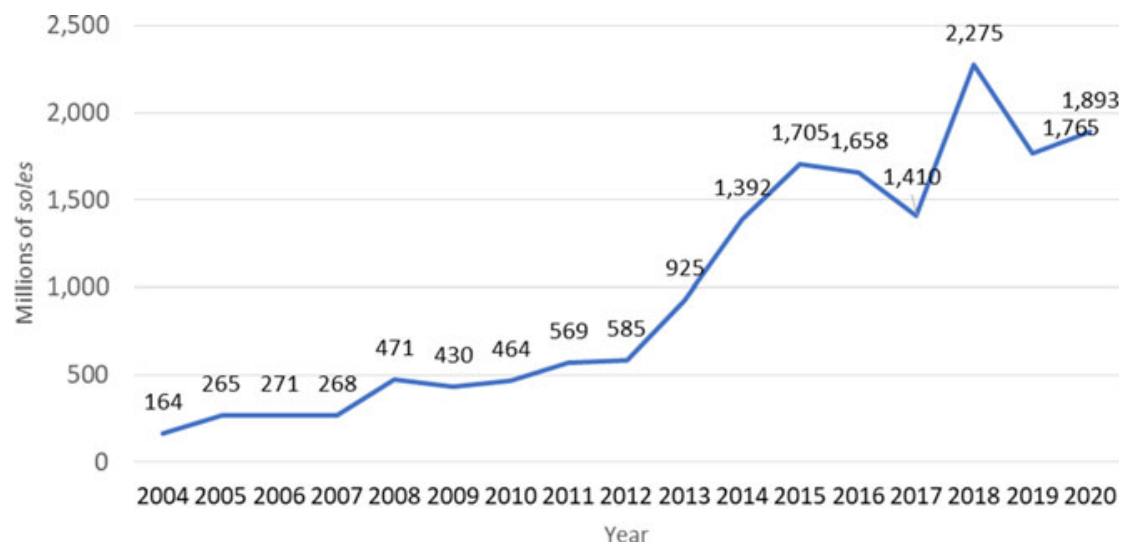

Figure 1. SIS Initial Budget (in Millions of soles)

Source: Author's elaboration based on Sistema de Consulta Amigable - Ministerio de Economía y Finanzas (MEF) data.

the hospitals and health centres before they provided services. As Figure 1 shows, an important injection of funding for the health sector arrived: whereas the budget between 2008 and 2012 was 400-500 million soles, it was 900 million soles (around US $\$ 300$ million) by 2013 . The increase in funding was not the only important change - a MINSA team, composed of previous PRAES members, prepared a group of 23 laws that had the goal of making AUS possible. Instead of sending the bills to Congress, the executive decided to ask for legislative powers and passed the laws through legislative decrees. Between September and December 2013, the executive enacted the 23 legislative decrees.

Three main decrees attempted to tackle MINSA facilities' shortage of human resources and infrastructure. One of them tried to make doctors' wages homogeneous across the country, as well as giving them an incentive to work in remote areas through a bonus system. Another decree attempted to make the investment in infrastructure a more expedited process, together with the project of building 11 new national hospitals, 23 regional and 170 provincial. A third decree proposed the exchange of services between the public health system and EsSalud, as well as purchasing services from the private sector. Some exchange of services has started to take place, although the payment for those services has been slow. The main problem with hiring private services has been that some services are overvalued, in which case SIS ends up paying more for a service in a private clinic than a private insurer would pay. Another problem is the lack of regulations for emergency care of public-sector affiliates in private clinics. ${ }^{88}$ The sustainability of this process is a concern: if the purchase of private services was posed in order to decongest the public sector, until when and to what extent will the public sector continue to acquire private services? The worry is for it to become a long-term, and therefore financially unviable, solution.

\footnotetext{
${ }^{88}$ Alejandro Arrieta, 'Serie sobre hospitalizaciones evitables y fortalecimiento de la atención primaria en salud: El caso de Perú', Inter-American Development Bank Discussion Paper 275, 2012.
} 
Table 2. Infrastructure and Human Resources in the Public Health Sector

\begin{tabular}{|cccc}
\hline Year & Hospital beds & Beds (per 1,000 people) & Physicians \\
\hline 2007 & 25,389 & 1.6 & 12,087 \\
\hline 2008 & 25,337 & 1.6 & - \\
\hline 2009 & 25,607 & 1.5 & 15,056 \\
\hline 2010 & 25,580 & 1.5 & 15,607 \\
\hline 2011 & 25,969 & 1.5 & - \\
\hline 2012 & 26,145 & 1.5 & 17,007 \\
\hline 2013 & 26,700 & 1.5 & 18,723 \\
\hline 2014 & 27,970 & 1.6 & - \\
\hline 2015 & 28,012 & 1.6 & 21,031 \\
\hline 2016 & 28,254 & 1.6 & 22,797 \\
\hline 2017 & 27,619 & 1.6 & 23,226 \\
\hline 2018 & 28,493 & 1.6 & 26,360 \\
\hline 2019 & 29,141 & 1.6 & - \\
\hline
\end{tabular}

Note: 'Beds (per 1,000 people)' includes beds in private clinics and EsSalud.

Source: Author's elaboration based on the following MINSA data. Beds:

Registro Único Nacional de Información en Salud (REUNIS), 2020, available at www.minsa.gob.pe/reunis/recursos_salud/ index_camas_hospitalarias.asp, last access 6 Aug. 2021. Physicians: Compendio estadístico: Información de recursos humanos del sector salud, Perú 2013-2018 (Lima: MINSA, 2019).

As Table 2 shows, the increase in physicians, and particularly hospital beds, in the public sector was not very rapid. The rate at which infrastructure and human resources were growing did not meet the large increase in formal insurance coverage: over 17 per cent of the population (over 5 million Peruvians) affiliated to SIS between 2009 and 2015, as shown in Figure 2. In 2018, there was one physician per 675 SIS affiliates. AUS was a reform that did not specify its funding nor how to overcome the infrastructure gap the public system had in order to expand access to healthcare. Given the lack of policy specifications, the progress of the reform was very slow. The lack of commitment to the policy from non-programmatic parties led to a poorly specified reform and hence a deficient implementation.

AUS only began to move forward when one of the USAID technocrats who had been involved since agenda-setting, de Habich, became health minister. Her arrival led to an increase in funding as well as a set of decrees designed to help with the shortage of infrastructure. Even then, as members of the MINSA team in charge of the implementation of AUS commented, one of their main challenges was the instability of funding. For the former health minister, the funding was at risk because it depended on 'the ability of MINSA to negotiate with MEF, which has always been weak'. ${ }^{89}$ As de Habich pointed out, this was fortunately not an issue in her case. ${ }^{90}$

\footnotetext{
${ }^{89}$ Author interview with Midori de Habich.

${ }^{90}$ Members of both MINSA and MEF noted that de Habich was able to convince the minister of economy and his team due to the fact that she was an economist herself. She had studied in the same university
} 


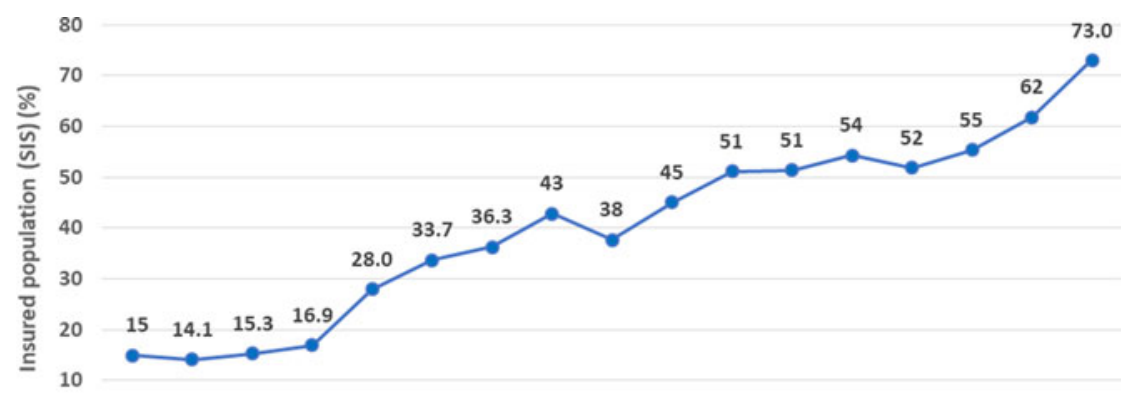

20042005200620072008200920102011201220132014201520162017201820192020

Year

Figure 2. Insured Population (SIS) (\%)

Source: Author's elaboration based on Encuesta Nacional de Hogares, Instituto Nacional de Estadística (2004-10) and MINSA (2011-20).

The revision of PEAS every two years never happened. ${ }^{91}$ Since most public health facilities were not able to provide these benefits due to their lack of infrastructure and human resources, revising a plan that was impossible to fulfil did not make much sense. The conditions PEAS included were unrealistic, for instance, in terms of the time that the personnel should take to provide a certain service or the exact number of tests that they should apply to a patient.

In the case of the private sector, PEAS was simply irrelevant. Private insurers sell two types of insurance schemes: plans for those who want to get medical attention in the network of private clinics (entidades promotoras de salud, EPSs), and plans for specific coverage (e.g. cancer). The inclusion of PEAS for the first type of plan was not a problem since, as in the case of EsSalud, its benefit plan was already extensive. They just had to add the coverage for some additional interventions and, as former executive of Pacífico Seguros - one of the biggest insurance companies in Peru noted, they did so economically. For former Health Minister de Habich, it is best to ignore the part of the law that talks about PEAS and the private sector. ${ }^{92}$

PEAS was envisioned as the technical tool that would make AUS more tangible, providing users with a set of benefits they had the right to in both the public and private sectors. As de Habich commented, PEAS was important because it would allow citizens to hold the system accountable. However, when asked about the current situation, where PEAS does not mean much for citizens since access is highly limited in many places, she noted that PEAS 'stated where we should move towards. As a policy tool, it is what you want to happen ... an instrument of what should be. ${ }^{93}$ She agreed that PEAS could not be revised as not even the original plan can be provided.

as most MEF members and had previously worked for the Banco Central de Reserva del Perú (Peruvian Central Reserve Bank).

${ }^{91}$ The USAID-funded project PolSalud (a continuation of PRAES) was in charge of providing technical assistance for this revision. Author interview with Alfredo Sobrevilla.

${ }^{92}$ Author interview with Midori de Habich.

${ }^{93}$ Ibid. 
By 2020, almost 23 million Peruvians (73 per cent of the population) were affiliated to the government's free insurance scheme, as seen in Figure 2. While the number of affiliates grows, so do the complaints regarding the public system's capacity to respond to this enormous demand. In theory, this public insurance could cover everything today, as affiliates can also access a 'complementary plan' to cover any other health intervention up to 7,900 soles (US\$2,600) and 'extraordinary coverage' in case the cost for these extra interventions surpasses this sum. The former SIS leader noted that they were spending a third of their budget on this and that was precisely why they 'did not want them [the affiliates] to know'. ${ }^{94}$ Moreover, 40 per cent of SIS affiliates are in rural areas of Peru, where access is more limited. When the required technology or personnel is not available in a facility, patients can be referred to the nearest facility able to cover the need. In the majority of cases, these patients do not go to the referred facility. According to official MINSA data, in 2015, only 0.5 per cent of referred patients nationally accessed the required care. One of the main reasons is that patients cannot afford transport to a different facility.

Despite its shortcomings, AUS has brought more organisation to the chaotic system of public provision. The reform also led to the creation of the Superintendencia Nacional de Salud (National Health Superintendency, called SUSALUD since 2014), in charge of protecting the rights of all users of health services by monitoring health facilities and insurance entities (both public and private). ${ }^{95}$ Moreover, AUS brought the possibility of increasing funding for the sector, which more than doubled between 2012 and 2014. MINSA officials' main concern is the stability of the funding. There is uncertainty with regards to how much money MEF will give year by year. Many experts concur that the best way to give stability to the funding is to calculate a premium that could become the base for the assignment of funding, then funding would increase as the number of affiliates increases. ${ }^{96}$

The AUS policy-making process in Peru shows that when a policy reform is approved without enough planning behind it, the reform's sustainability depends on short-term factors such as the presence of individual actors. The implementation of AUS only progressed when the former leader of the USAID projects became health minister. A policy designed by technocrats needed to be carried by committed politicians during its implementation to succeed. However, there has been no political commitment to the healthcare reform. One of the main signs of this is the inconsistent funding the reform has suffered. Given the shortage of infrastructure and human resources, most public health facilities are not able to provide the promised interventions and benefits. As a health official noted, Peruvians are given 'a right limited to budget availability'. 97

\section{Conclusions}

I traced the influence of the absence of political parties' programmatic commitment throughout agenda-setting, debate and implementation to explain why the

\footnotetext{
${ }^{94}$ Ibid.

${ }^{95}$ So far, they have two offices (Lima and Chiclayo). The projection is to open one in each region.

${ }^{96}$ This is hard because there is a lot of 'filtration' in the system (people who do not qualify are included). SIS calculates this is between 10 per cent and 30 per cent of affiliates. If the budget were to be assigned based on a premium, SIS would be forced to verify its pool of affiliates.

${ }^{97}$ Author interview with José del Carmen.
} 
healthcare reform failed to deliver its promised expansion of benefits. This question is particularly relevant today. Healthcare systems across the world have been put to the test during the Covid-19 pandemic.

Political parties without core values and without commitment to healthcare allowed the reform's policy-making process to be led by technocrats from USAID-funded projects. PHRplus, a five-year project (2000-5) funded by USAID, introduced the AUS reform onto the political agenda, with the collaboration of private-sector representatives. The need for policy that would expand access to healthcare to excluded populations was slowly penetrating the agenda of Latin American countries. International organisations such as the World Bank, the WHO and the PAHO started to advocate for such expansion in the early 2000s. Moreover, the PAHO had cooperated with the interim Peruvian government in 2001 to put together a proposal to extend social security to informal workers. While political parties were not interested in the healthcare issue, the USAID project took the initiative of designing a reform that, while extending access to many people, would maintain the fragmented system and leave the interests of the private provision and insurance sectors untouched. The lack of programmatic parties in Peru is closely linked to the power technocrats wield in policy-making, as has been shown for other policy areas. ${ }^{98}$

During debate, the main parties in Peru did not care to specify the necessary funding and infrastructure provisions for the reform. Technocrats without partisan ties dominated the process, crafting a poorly specified policy. They considered that provisions regarding funding and infrastructure were unnecessary before the implementation stage and could hinder the passage of the bill. The implementation of the Peruvian reform has been contingent on short-term factors such as the presence of individual actors, and there is no stability in terms of funding. Due to a lack of funding and an infrastructure gap in the public sector, the AUS reform moved slowly during its first years. When one of the USAID technocrats who had been involved since agenda-setting became health minister in 2012, the funds destined for the reform increased. However, a key challenge is the instability of funding. The promoters of AUS, in a context of politicians lacking programmatic commitment to the reform, did not provide a feasible or sustainable solution to the problems Peru faced regarding access to healthcare.

The reform sought to tackle a system that discriminated based on the socioeconomic status of its citizens. Whereas more Peruvians enjoy formal coverage thanks to AUS, the shortage of means to effectively provide such coverage gets in the way. This context generates a type of discrimination based on the availability of services: if you live in a place where there are resources to provide services, you could indeed get financially covered for a large set of interventions; if not, you are covered only in theory.

The Peruvian case demonstrates that in the context of parties without commitment to healthcare reform, technocrats who lack incentives to provide clearly defined policy options can dominate the policy-making process. A policy designed

\footnotetext{
${ }^{98}$ On the role of economic technocrats, see Dargent, Technocracy and Democracy; Alberto Vergara and Daniel Encinas, 'Continuity by Surprise: Explaining Institutional Stability in Contemporary Peru', Latin American Research Review, 51: 1 (2016), pp. 159-80.
} 
by technocrats still needs political commitment during its implementation to succeed. Although technocrats may provide the technical knowledge that nonprogrammatic parties lack, a healthcare reform needs the support of politicians during its implementation. Politicians are responsible for granting sustained funding and tackling the infrastructure needs that transform the reform into effective access to healthcare. The lack of political commitment has as its main repercussion a poorly specified legislation and deficient implementation, and ultimately lower welfare for people.

Finally, a social policy reform that does not have the commitment of any of the major political forces in the country may have the advantage of not generating opposition to it and thus, in theory, not being vulnerable to the next party in government. However, this type of reform does not endure over time as the lack of political commitment hinders its feasibility and sustainability.

Supplementary material. The supplementary material for this article can be found at https://doi.org/10. $1017 /$ S0022216X21000493

Acknowledgements. The author would like to thank Evelyne Huber, Jonathan Hartlyn, John Stephens, Cecilia Martinez-Gallardo and Frank Baumgartner for their invaluable comments and constant encouragement; Eduardo Dargent for his support during fieldwork; and Steve Levitsky for his helpful feedback on an earlier version of this article. The author is also grateful to Bo Garfinkel and Gianfranco Silva for their excellent research assistance, Luke Chanarin for reading several versions of the manuscript and Ryan Carlin for providing inspiration for the article's title. The author also thanks the anonymous reviewers for their very helpful feedback, as well as the participants of the 2017 MPSA conference. Finally, the fieldwork the author conducted for the completion of this project was possible thanks to research fellowships from the Institute for the Study of the Americas, the Graduate School, and the Political Science department at UNC Chapel Hill, and the APSA Fund for Latino Scholarship.

\section{Spanish abstract}

La reforma aprobada en Perú en 2009 durante un gobierno de derecha se diferencia de otros intentos similares en la región para expandir el acceso a la salud. Los partidos de izquierda en Perú fueron extremadamente débiles durante la hechura de esta política pública y los partidos políticos no eran programáticos. Basado en trabajo de campo original, este artículo demuestra cómo los partidos que carecían de valores centrales uniendo a sus líderes y no tenían compromiso con la reforma de salud no se preocuparon por la definición de especificaciones relacionadas con el financiamiento e implementación de la misma. Más bien, los tecnócratas dominaron el proceso, lo que, junto a la falta de compromiso de parte de actores políticos claves, llevó a una política pública pobremente especificada y a una implementación deficiente.

Spanish keywords: reforma del sistema de salud; partidos políticos no programáticos; tecnócratas; Perú; política en América Latina; AUS

\section{Portuguese abstract}

A reforma aprovada no Peru em 2009 durante um governo de direita se desvia de tentativas semelhantes na região de expandir o acesso à saúde. Os partidos de esquerda no Peru foram extremamente fracos durante o processo de formulação de políticas públicas e os partidos políticos se comportavam de maneira não programática. Com base em pesquisa 
de campo original, este artigo demonstra como partidos que careciam de valores fundamentais para unir seus líderes e não tinham compromisso com a reforma de saúde não se importaram com a definição de especificações a respeito de financiamento e implementação. Em vez disso, os tecnocratas dominaram o processo de formação de políticas, o que, acompanhado pela falta de compromisso dos principais atores políticos, levou a uma política pública mal especificada e implementação deficiente.

Portuguese keywords: reforma da saúde; partidos políticos não programáticos; tecnocratas; Peru; política latino-americana; AUS

Cite this article: Ponce de Leon Z (2021). Healthcare Reform out of Nowhere? Policy Reform and the Lack of Programmatic Commitment in Peru. Journal of Latin American Studies 53, 493-519. https://doi.org/ $10.1017 /$ S0022216X21000493 